7. Сокол, О. В. Морфологічні особливості сім'янок видів роду Arctium L. [Текст] / О. В. Сокол, Т. Б. Вакуленко // Вісті Біосферного заповідника "Асканія-Нова". - 2012. - Т. 14. - С. 258-264.

8. Сокол, О. В. Морфологічні особливості будови квітки рослин роду Arctium L (Asteraceae) [Текст] / О. В. Сокол // Інтродукція рослин. - 2015. - № 2. - С. 72-76.

9. Шмидт, В. Н. Математические методы в ботанике [Текст] / В. Н. Шмидт. - Л.: Издательствово Ленинградского университета, 1984. - 288 с

10. Зайцев, Г. Н. Математическая статистика в экспериментальной ботанике [Текст] / Г. Н. Зайцев. - М.: Наука, 1984. - 425 с.

Рекомендовано до публікаиії д-р біол. наук Булах П. Е. Дата надходження рукопису 20.01.2017

Сокол Оксана Владимировна, соискатель, ведущий инженер, Лаборатория медицинской ботаники, Национальный ботанический сад им. Н. Н. Гришка НАН Украины, ул. Тимирязевская, 1, г. Киев, Украина, 01014

E-mail: sokoloksana23@ukr.net

УДК 616.993(477.72)

DOI: 10.15587/2519-8025.2017.93634

\title{
THE STATE OF NATURAL LEPTOSPIROSIS CELLS ACTIVITY AND FUNCTIONING IN THE DRY STEPPE ZONE OF THE NORTHWEST BLACK SEA REGION
}

\author{
(C) S. Sushko
}

Територія аридно-степової місцевості по кліматичнічним та ландмафтно-сочіальним умовам в значній мірі визначає потенціал і активність локальних осередків лептоспірозу.

На основі результатів серологічного контроля гризунів та звітних даних лабораторій СЕС о результатах аналітичних досліджень, був виконаний аналіз і установлено, щэо дія факторів і міняє просторову, видову і етіологічну структуру природних осередків лептоспірозу

Ключові слова: ензоотичне функціонування, осередки, лептоспіроз, природна інфекиія

\section{Introduction}

Steppe zones of Eurasia are located from Hungary to Transbaikal and North-Eastern provinces of China, forming a continuous strip from $150 \mathrm{~km}$ (Hungarian Puszta) to $600 \mathrm{~km}$ (Kazakhstan) wide [1]. Till the beginning of the $\mathrm{XX}^{\text {th }}$ century the whole area was almost treeless, but covered with low grass, predominantly gramineous plants that could tolerate occasional drought. Primarysteppe plant community consisted not only of gramineous plants, but also of various species of wormwood, ephemerous and xerophilous plants with powerful rootstocks (potato, succulent roots) [1]. Steppe plants tissue is "rich" in cellulose with a limited content of tannins and saponins, which contributes to their rapid soil utilization and to the intensive circulation of biogenic compounds [1]. The zonal steppe soils are notable for predomination of common chernozem with high and very high fertility potential, which southward gradually change into brown and alkaline soils of loamy clay type [1]. Volumes of humidity within Eurasian steppe zone range from 280 to $500 \mathrm{~mm}$ per year. Yearly average temperatures in different parts of the steppe zone vary greatly, with the total amplitude of winter and summer temperatures exceeding $70{ }^{\circ} \mathrm{C}$ [2].

A big amount of plant food and its long-term storage after natural drying up is the main condition for the existence of the faunal biodiversity of the steppe and savannah biomes of the world that are characterized by a wide variety of species of ungulates and rodents [2]. High density of the latter stipulates the appropriate existence of complex parasite-coenotic systems that can effectively maintain the stability of ecosystems through rapid response to their biotic components of higher order (birds and mammals) [2]. The structural-trivial organization of parasite- coens of steppe ecosystems is evolutionary adapted to the climatic, soil, landscape and biotic peculiarities of local areas, organically combining microbial excitants, arthropods, plants and animals [2]. Thus, typical for the steppe areas are multi-range circulations of pathogens in chains "animal-soil-plant-animal" additionally including carrying agents (acarians and insects), disseminators (birds, predators) and reserve objects of pathogen experience (soil onecelled protozoa, amoeba, algae) [2].

There are a certain number of pathogens of naturally infectious diseases; the most characteristic of the steppe areas is bacteriosis pathogens - anthrax, emphysema carbuncle, tularaemia, listerellosis, pasteurellosis, enteral yersiniosis and zoonotic plague. There are also numerous viroses - rabies, haemorrhagic fever, tick-borne encephalitis, complicated by the spread of rickettsiosis and clamidiosis and blood-parasitic infections [3]. The ecology of these pathogens and the ecological-epizootic aspects of disease manifestations caused by them are closely linked to the biotic and abiotic substances of local ecosystems and act as components of the mechanisms of their self-regulation [3]. Among the "steppe" pathogens of natural infections there are usually no waterleaf microorganisms, whose ecology involves compulsory circulation through natural reservoirs, aquatic and semi-aquatic animals. Leptospira microorganisms are typical representatives of such evident waterleaf-microorganisms; their habitats are represented by slowly running freshwater reservoirs within the tropics, subtropics, steppe, forest and tundra zones [3]. The natural circulation conditions for leptospira in the steppe, desert, semi-desert are unfavorable, but the massive manifestations of leptospirosis among domestic, synanthropic and wild animals in the Black Sea steppes indicate the possibility of such a circulation. 


\section{Literature review}

To studying of questions of natural leptospirosis cells activity and functioning are devoted works of foreign and local scientists: A. M. Yeryna [1], V. S. Mordkovich [2], O. V. Vasylyuk, A. V. Yena, A. A. Kuzemkova [3], N. P. Naumov [4], Havura V. V., Oleksenko O. V. [5], Oleksenko O. V. [6], V. V. Tarasova [7], A. B. Ruchyn [8], I. V. Nakonechny, V. V. Serebryakov [9].

In their works they study methodological principles of statistical modeling and forecasting of socioeconomic phenomena, various modifications of dynamics models, structure and relationships, conditions of adaptation to the specific objects of modeling. Publications are devoted to the complex research of ecology of pathogens of naturally - concentrated infections and their functional roles in ecosystems in the south of Ukraine. According to the results of years of researches, the authors established patterns of formation and functioning of infection cells of natural nozoforms. Our research is devoted to the ecological role of rodents in the territory of dry steppe zone of the north-western Black Sea coast.

\section{Aim and research problems}

The aim of the article is to study the structural and functional organization of leptospirosis cells, existing on the territory of mosaic agricultural landscapes of Northwest Black Sea coast.

Research problems:

1. To study and reveal ecological, biotopical and biocenotical features of different types of leptospirosis cells, that function in a mosaic agricultural landscapes of the region.

2. To set the structural organization of different types of leptospirosis cells in the territory of the steppe zone of the North-West Black Sea.

3. To investigate the functional organization of natural cells.

4. To find out the ecological role of leptospirosis cells, functioning as a part of the field agro-ecosystems in the region.

5. To find out the ecological role of leptospirosis cells, functioning as a part of the field agro-ecosystems of the region.

6. To investigate the functional organization of natural, synantropic, mixed and farm cells.

The ecology of leptospira and its enzootic circulation on the territory of the arid-steppe zone are analyzed. As the model territory we have chosen a few plots of the dry steppe type in the interstream area between the Firth of Tiligul and the Firth of Berezan, Mykolayiv region, Ukraine.

4. Functional organization of leptospirosis cells in the steppe zone of the North-West Black Sea coast

The factual data used in the article are mainly the results of our field, laboratory and analytical research. We also used some retrospective data: archives, reviews, and research works. A contrastive analysis was conducted to compare the newest factual information, actual research results with the historical data, which helped to establish the basic regional peculiarities of the survey target as well as the dynamics of its changes in the specific, biocoenotic and landscape characteristics of the model territory. During our research (2014-2015) 23 routes with the total length of over $76 \mathrm{~km}$ were made; zoological, environmental, epizootic, landform and biotope characteristics were investigated within the dry steppe (coastal) strip of territory between the Tiligul and the Berezan estuaries of the river Dnieper.

The current investigation was based on an integrated approach combining general biological and specific scientific methods. The peculiar character of the investigation determined the application of field techniques and laboratory-based (serological) methods founded on standard, conventional techniques [4]. The primary factual data regarding the epizootic situation have been obtained owing to laboratory inspection of the animals for leptospirosis with due consideration of inspection record of the state of different habitats in their seasonal and perennial variability.

To record primary accounting data on the species, absolute and relative density of rodents we used two main methods: the belt transect technique and the sample plot (area) technique [4]. All the recorded digital data were processed automatically on a PC using the software package "Excel - 2000/Statistics". Additionally, certain computer calculations were carried out on the basis of correlation, dispersion, factor and cluster analysis using the software package "Excel - 2000 - Analysis" [4].

The territory of the dry steppe strip of the Northwest Black Sea region is heterogeneous by climatic and landscape conditions, which in some specified sense determines the potential and activity of the local natural infections cells, concentrated there. The process of steppes' transforming into the field agricultural landscapes required creating numerous tree belt areas and artificial reservoirs as drinking places for domestic animals that created favorable conditions for the emergence and existence of the newest faunal clumps of the field type within the zonal steppe. Today, along with the indigenous species of the steppe zone and transpalaearctic habiti there is a variety of newer species in their structure that were previously absent - forest species of voles of the Cleothrionomis genus, water rat Arvicola terrestis, field mouse Apodemus agrarius, wild boar Sus scrofa, roe deer Capreolus capreolus, raccoon dog Nyctereutes procyonoides. Accordingly, rather rapid landscaping and faunal transformation of steppes into a mosaic agricultural landscape resulted in a disturbance of the parasitecoenotic complexes, locally "closed" in mammals and rather characteristic for the given territory. One of the components of the local parasite community is leptospiroses that all over the Northern Black Sea Area have long conditioned locally enzootic circulation involving wetland, bottomland, valley and ravine forest habitats. The latter are location centers of specific intrazonal mammals and also provide the saprophytic phase of leptospirosis circulating.

Leptospiroses on the territory of the steppe zone in the Southern Ukraine were widely studied at the end of last century [5]. The investigations proved the existence of numerous Leptospira hosts that can generally be divided into two main groups. The first is represented by wild (exanthropic) species, the second - by domestic species that are respectively the strain carriers of Leptospira, which is allochthonous for the environment of the research 
zones. To assess the situation objectively it seems evident that we should point out a third group - synantropic species that are ecologically more closely related to human settlements and objects of animal breeding.

We have used the above mentioned survey results as primary data in our investigation to conduct a comparative analytical generalization based on newer materials. For this purpose in 2014-2015 we systematically studied the state of natural leptospirosis cells activity and recorded their activity rates on the territory of dry steppe zone of the coastal strip between the Tiligul and Berezan Estuaries on the territory of the Mykolaiv region. Our main survey target was field mouse-like rodents and domestic animals.
Even the first comparative generalization of the statistics regarding the agricultural production of the research area in 1991, 2003 and 2014 indicated very significant changes in the socio-economic existence conditions of the rural population of the region and tangible changes in the structure of the agricultural production. Thus, the main branch of agricultural production appeared the crop production, whose cropping capacity is nowadays $10-18 \%$ higher than in the 90's of last century, considering the $3-5 \%$ reduction of tillable acreage. The main characteristic feature of the farming proved to be the commanding leadership of two crops - winter wheat and sunflower, occupying $82.3 \%$ of the tillable acreage in Table 1.

Table 1

Acreage indicators under different crops

\begin{tabular}{|c|c|c|c|c|c|c|c|}
\hline \multirow{2}{*}{ Years } & \multirow{2}{*}{$\begin{array}{c}\text { Total crop area, } \\
\text { thous. ha. }\end{array}$} & \multicolumn{2}{|c|}{ Winter crops sown, thous. ha. } & \multicolumn{2}{|c|}{ Sunflower sown, thous. ha. } & Spring barley sown, thous. ha. \\
\cline { 3 - 8 } & Total & $\begin{array}{c}\text { \% of the total } \\
\text { crop area }\end{array}$ & Total & $\begin{array}{c}\text { \% of the total } \\
\text { crop area }\end{array}$ & Total & $\begin{array}{c}\% \text { of the total } \\
\text { crop area }\end{array}$ \\
\hline 2014 & 3048,8 & 2099 & 59,5 & 949,8 & 26,9 & 307,8 & 87 \\
\hline 2015 & 2295,2 & 949,8 & 26,9 & 1345,4 & 38 & 700 & 19,85 \\
\hline
\end{tabular}

The livestock sector, on the contrary, has sharply lost its positions and at the present time is represented only by small amounts of animals owned by farmers (2550 cattle heads) and owned by the private sector (23 cattle heads per one farm) in Table 2 .

Under these conditions, in crop rotations the sowing of permanent forage grasses and corn is almost absent; much of straw and other stubble weeds is not stored up as food reserve, but is immediately ploughed into the soil. All that essentially reduced anthropogenic and purely agronomical pressure on the environment of the research area and respectively changed the existence conditions of natural Leptospira hosts - mouse-like rodents.

The long-term research records of density indices of mouse-like rodents in the fields of the research area are shown in Table 3. For objectivity's sake we analyzed the averaged number of inhabited rodents' holes, related to the habitat type, registered within 1 ha of area and relevant for November 1 of each year. Such a manner was used to record the survey results of the previous years, which naturally determined the procedure of recording our own results in Table 3.

Table 2

Number of serologically investigated domestic animals in the North-West Black Sea Region

\begin{tabular}{|c|c|c|c|c|c|c|c|c|c|c|}
\hline \multirow[b]{2}{*}{ Years } & \multirow[b]{2}{*}{$\begin{array}{c}\text { Total } \\
\text { amount of } \\
\text { samples in- } \\
\text { vestigated }\end{array}$} & \multicolumn{3}{|c|}{ Including cattle } & \multicolumn{3}{|c|}{ Including pigs } & \multicolumn{3}{|c|}{ Including horses } \\
\hline & & $\begin{array}{c}\text { Total number } \\
\text { of samples } \\
\text { investigated }\end{array}$ & $\begin{array}{l}\text { Among } \\
\text { them posi- } \\
\text { tive sam- } \\
\text { ples }\end{array}$ & $\begin{array}{c}\% \text { of posi- } \\
\text { tive sam- } \\
\text { ples }\end{array}$ & $\begin{array}{l}\text { Total num- } \\
\text { ber of sam- } \\
\text { ples inves- } \\
\text { tigated }\end{array}$ & $\begin{array}{l}\text { Among } \\
\text { them posi- } \\
\text { tive sam- } \\
\text { ples }\end{array}$ & $\begin{array}{c}\% \text { of posi- } \\
\text { tive sam- } \\
\text { ples }\end{array}$ & $\begin{array}{c}\text { Total num- } \\
\text { ber } \\
\text { of samples } \\
\text { investi- } \\
\text { gated }\end{array}$ & $\begin{array}{l}\text { Among } \\
\text { them posi- } \\
\text { tive sam- } \\
\text { ples }\end{array}$ & $\begin{array}{c}\% \text { of posi- } \\
\text { tive sam- } \\
\text { ples }\end{array}$ \\
\hline 2014 & 543 & 253 & 32 & 12,64 & 161 & 92 & 57,1 & 10 & 2 & 20 \\
\hline 2015 & 637 & 459 & 78 & 17 & 154 & 94 & 61 & 37 & 9 & 24,3 \\
\hline
\end{tabular}

Note: developed by the auther

Table 3

Calculated density indices of mouse-like rodents' burrows (without details about the species) in the biotopically various plots of the mosaic agricultural landscapes

\begin{tabular}{|c|c|c|c|c|c|c|}
\hline \multirow{2}{*}{ Years } & \multicolumn{7}{|c|}{ Presence of burrows per 1 ha. on November 1 } \\
\cline { 2 - 7 } & Winter crop & Stubble field & Forest belts & Ravine slopes & Virgin plots & Fallows \\
\hline 1991 & $19,3 \pm 2,7$ & $78,3 \pm 6,1$ & $56,6 \pm 14,5$ & $9,1 \pm 3,0$ & $14,8 \pm 5,2$ & $23,5 \pm 7,9$ \\
\hline 1996 & $12,9 \pm 3,4$ & $519 \pm 53,8$ & $103,3 \pm 24,2$ & $13,1 \pm 5,2$ & $23,1 \pm 7,2$ & $48,8 \pm 8,6$ \\
\hline 2002 & $29,5 \pm 1,9$ & $67,1 \pm 9,0$ & $72,4 \pm 4,6$ & $23,1 \pm 2,8$ & $19,7 \pm 4,1$ & $39,2 \pm 5,1$ \\
\hline 2005 & $97,6 \pm 26,7$ & $170,5 \pm 11,4$ & $61,2 \pm 3,2$ & $27,4 \pm 2,1$ & $21,2 \pm 4,5$ & $36,1 \pm 3,9$ \\
\hline 2010 & $19,1 \pm 2,4$ & $54,6 \pm 8,1$ & $79,4 \pm 11,1$ & $15,1 \pm 3,6$ & $16,8 \pm 2,7$ & $25,3 \pm 4,6$ \\
\hline 2014 & - & $11,3 \pm 3,1$ & $17,5 \pm 7,2$ & $8,1 \pm 3,0$ & $11,1 \pm 2,4$ & $16,7 \pm 3,1$ \\
\hline 2015 & - & $15,8 \pm 2,4$ & $19,1 \pm 2,7$ & $8,9 \pm 2,6$ & $12,4 \pm 3,2$ & $18,3 \pm 4,0$ \\
\hline
\end{tabular}

Note: developed by the auther 
The comparative results of the density indices of mouse-like rodents in the field areas during 1991-2015 testify to conspicuous differences referring to the existence conditions of the Leptospira carriers in the field agricultural landscapes. The principal difference consists in normalizing agro-technical measures that in the 90's of the last century had the non-systemic character and provoked the formation and propagation of densest rodents' populations, namely common voles' (Microtus arvalis) ones on the cutover fields. Late summer and autumn improvements of the existence conditions for the existence and reproduction of voles naturally conditioned their mass migration to the winter crop fields, which resulted in their severe marauding. That factor is manifested in the general density indices of rodents, but such migration hazards for winter crops are minimized due to the summer-autumn drought in 2014 and 2015 and accordingly due to the crop failure. Under these terms, owing to the failure of cultivating extremely dry soil, most stubble fields were ploughed in October and November, but high concentration of rodents in the fields was not revealed.

Thus, during 1991-2015 the agro-technical factor gradually became particularly significant and at the present time it has become decisive in connection with the state of field populations of mouse-like rodents. The given conclusion is also confirmed by the relative stability of the density of rodent burrows in the tree belt areas, virgin and ravine areas that previously served as important temporary reservation. Undoubtedly, this function in the above mentioned habitats remained unchanged, but the volumes of temporary, yet extremely powerful rodents' reservation have undergone significant changes. In the 90's during a short critical period of rodents' living (from the stubble cultivation to the winter crop emergence) the capacity of reservation was accompanied by an absolute feeding imbalance of virgin habitats. However, in recent years there has been surveyed a veritable ecotopic reservation when only a small part of the population permanently exists in habitats without changing their autoregulation status. The overall conclusion is quite obvious - with the introduction of intensive farming technologies that require strict observance of time concerning certain types of cultural operations, the conditions for unanticipated propagation of mouse-like rodents and for their migrations to winter crop fields disappear. Therefore, in original ecotopes, such as tree belt areas, ravine and virgin areas, there exist only sparsely populated groups of rodents, whose numbers are all the year round limited by habitat feeding potential. Suchlike populations do not pose any serious migration hazard, which genuinely protects winter crops due to the lack of reservation accumulations of rodents and also, theoretically, strictly controls the formation of active epizootic cells and the corresponding source of the infectious agent.

For detailed verification of theoretical conclusions concerning the elimination of epizootic strain of Leptospira natural circulation under the existing conditions of agricultural production, the laboratory examination (serological survey) of mouse-like rodents was carried out during the autumn of 2014 and 2015. The goal of the laboratory investigation was to test blood serum samples (native and preserved on bibulous paper) for specific antibodies. The samples were examined by the use of a microscopic agglutination test (MAT) and lysis test. Serum dilution used in the preliminary examination was 1:25. Cultures of 4 reference strains of $L$. polonica serovar Sejroe (strain 493 Poland); Kabura serovar Hebdomadis (strain Kabura); serovar Grippotyphosa (strain Moskva V); Copenhageni serovar Icterohaemorrhagiae (strain M 20). The results of the serological screening of rodents from biotopically different parts of the territory between the Tiligul and Berezan Estuaries, carried out in the autumn of 2014 and 2015, are presented in Table 4.

Table 4

Number of field mouse-like rodents serum samples demonstrating antibodies against Leptospira of 6 serogroups

\begin{tabular}{|c|c|c|c|c|c|c|c|c|c|c|c|c|}
\hline \multirow{3}{*}{ Biotopes } & \multirow{3}{*}{$\begin{array}{c}\text { Total } \\
\text { number of } \\
\text { samples }\end{array}$} & \multirow{3}{*}{ Rodent species } & \multicolumn{10}{|c|}{ Number of positive samples with titre $1: 25$ and higher } \\
\hline & & & \multicolumn{2}{|c|}{ Sejroe } & \multicolumn{2}{|c|}{ Hebdomadis } & \multicolumn{2}{|c|}{$\begin{array}{l}\text { Grippo- } \\
\text { typhosa }\end{array}$} & \multicolumn{2}{|c|}{$\begin{array}{c}\text { Icterohaemor } \\
\text { rhagia }\end{array}$} & \multicolumn{2}{|c|}{ Mixed } \\
\hline & & & $\mathrm{n}$ & $\%$ & $\mathrm{n}$ & $\%$ & $\mathrm{n}$ & $\%$ & $\mathrm{n}$ & $\%$ & $\mathrm{n}$ & $\%$ \\
\hline \multirow{2}{*}{$\begin{array}{c}\text { Stubble crop } \\
\text { field }\end{array}$} & 117 & Field mouse & - & - & - & - & 7 & 6,0 & - & - & 2 & 1,7 \\
\hline & 23 & Steppe mouse & 3 & 13,0 & - & - & - & - & - & - & - & - \\
\hline $\begin{array}{c}\text { Stubble } \\
\text { sunflower field }\end{array}$ & 81 & Steppe mouse & 5 & 6,2 & - & - & - & - & - & - & 1 & 1,2 \\
\hline Winter crops & 207 & Field mouse & - & - & - & - & 9 & 4,3 & 1 & 0,48 & 2 & 0,96 \\
\hline Forest belts & 32 & Field mouse & - & - & - & - & 2 & 6,25 & 1 & 3,1 & - & - \\
\hline \multirow[b]{2}{*}{ Virgin plots } & 37 & Field mouse & - & - & - & - & - & - & - & - & 2 & 5,4 \\
\hline & 17 & $\begin{array}{l}\text { Steppe } \\
\text { mouse }\end{array}$ & - & - & - & - & - & - & - & - & - & - \\
\hline Total & 514 & $\begin{array}{c}2 \text { species/ } \\
35 \text { positive } \\
\text { samples, or } 6,8 \%\end{array}$ & 8 & 1,5 & - & - & 18 & 3,5 & 2 & 0,4 & 7 & 1,4 \\
\hline
\end{tabular}

\section{Research results and discussion}

Leptospirosis - a particularly dangerous, naturalzoonotic infection, caused by the pathogenic species of Leptospira interrogans, which parasitism in mammals causes severe lesions of systems and organs (most often kidneys and liver), accompanied by signs of jaundice, fever and hematuria [6]. Essentially, under the name leptospirosis they understand a group of infections, quite dif- 
ferent in the epidemic, pathogenic and clinical meaning, caused morphologically and systematically by close microorganisms of Leptospira [6], that are transmitted by alimentary, contact and aspiration ways and are characterized by fever, myalgia, scleritis, renal, liver, central nervous system, in some cases jaundice and hemorrhagic syndrome [7]. International classifier of Diseases (7-10 views) [7] retains distribution of leptospirosis according to the specific pathogen - icterohaemorrhagiae, grippotyphosa, hebdomadis, canicola more. Under this scheme (ICD-10) clinical signs of leptospirosis are defined as A27.0 with the presence of icteric forms as A27.8 with anicteric forms and A27.9 with forms of unspecified cases of leptospirosis [8].

Morphologically Leptospira have spinning and spiral-meandering shapes, length from 6-24 to 34-40 microns and $0.3-0.5$ microns of thickness, which shows typically hydrophilic micro-organisms, best adapted to the existence and active motility in liquid medium. The ends of microbes of leptospira are usually bent in the form of hooks, used in their morphological differentiation from other winding forms of microorganisms [8].

Under the electronic microscope in leptospira cells was revealed the presence of spiral proto plasma cylinder, coated with glycopeptide membrane. The whole leptospira is also covered with surface membrane; between it and cytoplasmic cover (inner membrane) there are two flagella, known as "axial threads". Each of them is attached to the basal body and intertwined with proto plasma cylinder but free ends are in the middle of the cell. Because of this specific cell structure of leptospira walls, they badly perceive aniline colors, so they are subjected to microscopy in a native culture, looking through in a dark field microscope view. Plain living organisms reflect light well and have thin and actively moving convoluted silver shapes [8].

In general epizootic terms the source of pathogenic leptospira is representatives of the "classic triad" - sick animals, carriers and convalescents. Allotment of infekta from the organism of clinically sick animals is observed with all excreta, in carriers - mainly with urine, which is associated with the pathogen localization exclusively in kidneys [8].

Spreading of the disease. Leptospira are organisms, whose existence is closely related to the populations of their natural host - common species of rodents, insectivores, omnivores and carnivores [9]. Therefore, animals and humans, influenced by these infectious parasitic diseases are recorded in all continents except Antarctica. Recent decades leptospirosis hold (in epidemic plan) undisputed leadership in the world among the most common zoonotic infectious diseases [9]. Traditionally high levels of stress of epidemic and epizootic situation of leptospirosis are mostly typical for middle and subtropical latitudes of the Northern and Southern hemispheres. Some areas with high population of leptospirosis are also in the area of tropical latitudes, mostly in Southeast Asia [9].

Stably high rates of disease intensity are kept in such populous countries as India, China, Japan, South Korea, East and West Coast of Africa, Central and South America, some countries of the Mediterranean and the Balkans [9]. The leptospirosis remains quite problematic in Europe. All this gives grounds to experts to declare in 2014 that the last decade of leptospirosis in the world killed far more people than the viral hepatitis. In severe cases and in ones of acute manifestation of leptospirosis even in the EU countries lethal consequences could reach more than in $56 \%$. Equally relevant is leptospirosis of farm animals, which has a significant and uneven distribution in the world, while "...polihamic etiological structure of infections and adaptation of leptospira feature greatly complicate diagnosis and limit the success of disease control measures". High rates of current intensity of leptospirosis in cattle and pig farming in Europe allow according to the level of socio-economic importance to equate this nozoform to such diseases as tuberculosis and brucellosis, which resulted in the middle of the last century in huge economic losses [9]. During 2000-2015 acute leptospirosis epizootic situation with farm animals was observed in Argentina, Brazil, Panama, Mexico, Germany, Hungary, the Netherlands, Great Britain, Poland, Bulgaria, in many African countries. Significant spread of leptospirosis among cattle is held in the Southern US states, Canadian West coast, the East coast of Australia, in the coastal areas of New Zealand. Clinically expressed cases of leptospirosis of swine, horses, dogs, cats and fur animals took place during the 1990-2010. In large volumes they are recorded in the US, Canada, Japan, China and numerous South-East Asian countries. Sporadic and local outbreaks destruction of sheep and goats are fixed in Southeastern Iraq, Turkey and some provinces of Iran, Afghanistan, India, in the Sahel area and the Balkans [10]. The territory of Ukraine has always been and remains quite uneven in the epidemic and epizootic manifestation of leptospirosis the highest level of epidemic intensity (on the border 3,5-6,0/100 thousand. population) are traditionally characteristic for the Dnieper area, the least $(0,1-$ $0,3 / 100,000$ population) are dominated in purely steppe regions of Southern regions. Over the last 25 years Ukraine's average level of intensity is ranging from 3.2 to $6.7 / 100$ thousand population [10], so leptospirosis has become the most common infection disease with a high percentage of severe clinical forms and mortality (ranging from 3 to $64 \%$ ). Only in the last decade the cases and outbreaks have occurred in Zakarpattia, Kirovohrad, Vinnytsia, Mykolaiv, Rivne, Ternopil and Ivano-Frankivsk regions. The highest epizootic and epidemic threat of leptospirosis is held in areas along the river valleys of central and Southern regions of the country. As for the Mykolayiv region, the epidemic manifestation of leptospirosis always had strong performance in the valley and Southern Bug in Mykolayiv. Since the early 80 s of the last century it was maintained the natural high activity center, located within Domanivsky area, periodically epizootic natural - farm foci of leptospirosis of mixed type are getting activity in the Eastern and Northern areas [10].

Etiology. Leptospirosis of animals and humans is caused by specific pathogens species of Leptospira interrogans, genus Leptospira, family Leptospirae, from the link Spirohaetales. In Berg determinants of bacteria edition 1997, Leptospira is included in the group of spirochetes, which generally combines 8 families Borrelia, Brachyspira, Cristispira, Leptonema, Lepto- 
spira, Serpulina, Spirochaeta, Treponema. Leptospira genus comprises ten species $-L$. biflexa, L. borgpetersenii, L. inadai, L. interrogans, L. meyeri, L. noguchii, L.parva, L. santarosai, L. weilii, L. wolbachii. Until the available time they have a rather vague ecological status and obviously unknown pathogenic potential, so many researchers tend to share these views for two groups, or specific eco-systems, the first of which - L. interrogans combines parasitic (pathogenic) leptospira, and the second - saprophytic (apathogens) L. biflexa [10]. Taxonomic criteria for the classification of strains of leptospira at intraspecific level serve their antigenic specificity - point of accounting of each serovar (serotype) from a related antigenically - it is a difference of 10 units titer. Closely related serovars (with a difference of 10-20 units titer) are summarized in serogroups. Despite some differences in relation to human all members of the species L. interrogans are potentially dangerous, Although the greatest importance is hold by representatives L. icterohaemorrhagiae, L. grippotyphosa, L. pomona, L. tarassovi, L. canicola, L. hebdomadis. To continuous parasitizing in the body of animals have adapted only some strains of small group of species - adapted leptospira 15-20 serovars s 7-10 serogroups, although there is always the potential danger from the side of strains of other serogroups [10].

The main factors of pathogenicity of leptospira species $L$. interrogans is an invasive ability and resistance to phagocytosis, but their main destructive role at parasites in the body is caused by the high level of antigenic stimulation and mechanical destruction of endothelial cells of capillaries. Factor of direct virulence of leptospira strain is the ability of the last to synthesize exotoxin, hemolysin, fibrinolysin, plasmocoagulase and hyalurolidase. Thanks to the last, leptospira parasites in tissues of the body causes local and systemic hemorrhage, numerous small necrotic formations in the liver, kidney, spleen, on the surface of the mucous membranes and skin thickness. In this case lipoglycoproteid of cell wall (cell of microorganism) is synthesized in excessive quantities and is included into the cytoplasmic membrane of the host cell. The factor of invasive activity causes penetration of leptospira through the mucous membranes, wounds, scratched skin and even through coherent, but macerated skin. Pathogens initially penetrate into the lymphatic vessels, and then - in the bloodstream, so dissemination of the body and of parenchymal organs occurs exclusively through hematogenous [10].

The obtained results seem to be curious and highly informative. The total number of positive serum samples equals $6.8 \%$, which is twice higher than the overall average seropositiveness indicators concerning field rodents in the Mykolaiv region during 1991-2008 [10]. In addition, only two species of rodents: field mouse and steppe mouse were investigated, the former inhabits open bioptopes of low-populated forest belts and virgin plots (primary reservations of species), the latter inhabits the undeveloped stubble crop and sunflower fields, with primary reservations being virgin areas near forest belts and brushwoods. A sample error is likely to occur in the investigation due to the absence of species collecting, because in fact the research material used was the dead bodies of rodents, collected on the ground surface after agro-technical measures were undertaken. Unfortunately, the seropositivity of other species of rodents: wood mouse (Apodemus sylvaticus), wild housemouse (Mus musculus L.), rat (Rattus), and also insectivorous red-toothed shrew (Sorex) and musk whitetoothed shrew (Crocidura) remained unexamined.

Despite the above mentioned restrictions in the study, the positiveness of serological survey clearly confirms host-dependence of Leptospira, field mouse demonstrates the dominating number of antibodies to its typical parasite - Leptospira Grippotyphosa, steppe mouse - to Leptospira Sejroe, antibodies to Leptospira Icterohaemorrhagiae were detected in small amount. Among seropositive samples that revealed mixed antibodies the combination Grippotyphosa + Icterohaemorrhagiae, common for field mouse was prevalent. It is noteworthy that antibodies to Leptospira Hebdomadis, typical of house-mouse, were not detected even in cross titers, which are quite probable for such low serum dilutions.

\section{Conclusions}

1. In tessellated structure of field habitats the most numerous mammal species, which are mouse-like rodents, determine the etiological factor and the activity of Leptospira natural circulation.

2. Despite modern agro-technical limitations of the number and density of field mouse and steppe mouse populations in the conditions of dry steppe territory between the Tiligul and Berezan Estuaries, these rodents save and maintain a stable circulation of mono-host, species-adapted Leptospira strains of 3 serogroups (Grippotyphosa, Sejroe, Icterohaemorrhagiae).

Prospects for further research lie in disclosing and experimental modelling of circulation mechanisms of Leptospira on the territory whose conditions do not allow realization of the extra-organismic (saprophytic) phase of the these microorganisms' existence.

\section{References}

1. Vasylyuk, O. V. Ostanni stepy Ukrai'ny: buty chy ne buty? [Last steppes of Ukraine: to be or not to be?] [Text] / O. V. Vasylyuk, A. V. Yena, A. A. Kuzemkova et. al.; O. P. Burkovskyi (Ed.). - Kyiv, 2013. - 44 p.

2. Mordkovich, V. S. Stepnye ecosistemy [Steppe ecosystems] [Text] / V. S. Mordkovich. - Novosibirsk: Academic Publishing House "Geo", 2014. - 244 p.

3. Ruchyn, A. B. Ekologiya populyatsy i soobshestv [Ecology of populations and communities] [Text] / A. B. Ruchyn. Moscow: Academy, 2006. -352 p.

4. Naumov, N. P. Ekologiya zhyvotnyh [Ecology of animals] [Text] / N. P. Naumov. - Moscow: Science, 1963. - 619 p.

5. Oleksenko, O. V. Zakonomirnosti epidemichnogo protsesu leptospirozu v Ukraini [Mechanisms of the leptospirosis epidemic process in Ukraine] [Text] / O. V. Oleksenko // Coliection of scientific works of staff member of P. L. Shupyk NMAPE. 2004. - Vol. 1. - P. 690-694. 
6. Havura, V. V. Evolutsiya epidemichnogo protsessu leptospirozu v Pivnichnomu regioni Ukrainy [The evolution of the leptospirosis epidemic process in the Northern region of Ukraine] [Text] / V. V. Havura, O. V. Oleksenko // Medication in Ukraine. 2003. - Issue 7-8. - P. 51-52.

7. Tarasova, V. V. Ekologichna statystyka [Environmental statistics] [Text] / V. V. Tarasova. - Kyiv: Center of educational literature, 2008. $-392 \mathrm{p}$.

8. Yerina, A. M. Statystychne modeluvannya ta prognozuvannya [Statistical modelling and forecasting] [Text] / A. M. Yeryna. - Kyiv: KNEU, 2001. - 170 p.

9. Nakonechny, I. V. Vozbuditeli prirodnyh infektsiy v ekosistemah yuga Ukrainy [Natural infectious agents in southern ecosystems of Ukraine] [Text] / I. V. Nakonechny, V. V. Serebryakov. - Kyiv: Tofi Kime, 2012. - 225 p.

10. Description - Introduction [Electronic resource]. - Global Historical Climatology Network-Daily. - 2009. - Available at: https://www.ncdc.noaa.gov/oa/climate/ghcn-daily

Рекомендовано до публікації д-р біол. наук Наконечний I. В. Дата надходження рукопису 24.01.2017

Sushko Svitlana, Postgraduate student, Department of biology and ecology, V. O. Sukhomlynsky Mykolaiv national University, Nikolska str., 24, Nikolaev, Ukraine, 54030

E-mail: suhko_sv@mail.ru

УДК 504.622:663.1 + 581.6

DOI: 10.15587/2519-8025.2017.94052

\section{АНАЛІЗ БІОЛОГІЧНИХ СПОСОБІВ ВІДНОВЛЕННЯ НАФТОЗАБРУДНЕНИХ ІРУНТIB}

\section{(C) Л. З. Шевчик, О. І. Романюк}

У статті проаналізовано та обтрунтовано перспективи сучасних біологічних методів відновлення нафтозабруднених трунтів. Наведено основні підходи до здійснення біоремедіації. Показано, щзо найбільш екологічно безпечним, економічно вигідним методом відновлення нафтозабруднених грунтів $є$ фіторемедіачія. Розглянуто методи фіторемедіації нафтозабруднених грунтів, вказано найбільш ефективні рослини-ремедіанти. Обгрунтовано доцільність фіторемедіації техногенних нафтозабруднених грунтів з використанням деревних актиноризних рослин

Ключові слова: нафтозабруднені трунти, біоремедіація, фіторемедіація, мікроорганізми-нафтодеструктори, рослини-ремедіанти, деградація земель, відновлення грунтів

\section{1. Вступ}

Нафтове забруднення є одним 3 найбільш небезпечних видів забрудненя навколишнього середовища. Його негативна дія на грунтово-рослинний покрив, атмосферне повітря, поверхневі та підземні води, здоров'я людей відзначається на всіх етапах промислового освоєння нафтових родовищ: буріння, переробки, зберігання, транспортування і ліквідації обладнання. Найбільшого впливу зазнають водні та наземні екосистеми. Серед компонентів наземних екосистем нафтою, насамперед, забруднюється грунт. Завдяки високій адсорбуючій здатності, нафта та нафтопродукти тривалий час зберігаються у ньому, спричиняючи як деградацію земель, так і створюють небезпеку проникнення полютантів у живильні ланцюги, однією з ланок яких є людина. Природне самоочищення грунту - довготривалий і складний процес, який не завжди завершується повним відновленням грунтової екосистеми. Тому вивчення і розробка екологічно нешкідливих прийомів прискоренної деградації нафти у грунтах є важливим завданням для вирішенні проблем техногенно порушених земель.

Ліквідацію нафтових забруднень грунту здійснюють різними методами: механічними - виїмка грунтів, збір нафтопродуктів; фізико-хімічними - спа- лювання, екстракція паром, промивання забрудненого нафтою грунту, сорбція, відновлення територій за допомогою ініційованого гумінового сорбенту, використання активованого торфу, очищення твердих поверхонь за допомогою гідрофобного органомінерального нафтового сорбенту та ін.; біологічнми - біоремедіація, фіторемедіація.

Аналіз літературних даних дає підстави стверджувати, що відомі механічні, хімічні та фізичні методи трудомісткі, довготривалі, потребують великих витрат, не забезпечують повноти очищення і часто приводять до вторинного забруднення навколишнього середовища іншими хімічними агентами. Крім цього вони ефективні лише при використанні на невеликих локальних територіях і при рівнях забруднення, як правило, більших 1 \% нафти у грунті [1-3]. Вищеперелічені способи дають одноразовий ефект, в той час як біологічні характеризуються тривалішим впливом і стабільним покращенням екологічної ситуації.

\section{3. Мета та задачі дослідження}

Мета дослідження - аналіз сучасних біологічних методів відновлення нафтозабруднених грунтів та можливостей їх використання на ранніх етапах ліквідації нафтового забруднення. 